\title{
Fine needle aspiration cytology (FNAC) in the diagnosis of canine hepatoid gland tumors- A comparative study with histopathology
}

\author{
Nihat YUMUŞAK ${ }^{1}$, Murat ÇALIŞKAN ${ }^{2}$, Osman KUTSAL ${ }^{3}$ \\ Harran University, Faculty of Veterinary Medicine, ${ }^{1}$ Department of Pathology, Şanlıurfa; Ankara University, Faculty of Veterinary \\ Medicine, ${ }^{2}$ Department of Surgery and ${ }^{3}$ Department of Pathology, Ankara, Turkey.
}

\begin{abstract}
Summary: In this study, cytological and histological findings of canine hepatoid gland tumors were evaluated for accuracy of cytologic diagnosis. Thirty two samples from dogs of different breed, sex and age were used in the study. Cytologic speciments were prepared by Fine Needle Aspiration Cytology (FNAC) and stained with May-Grünwald Giemsa (MGG). On the other hand, histopathologic tissue samples were obtained surgically. Samples were fixed in 10\% neutral formalin solution and embedded in paraffin by routine procedures and stained with hematoxylin-eosin (H\&E). In $84.37 \%$ of the samples taken from the 32 dogs included in the study, matching cytological and histopathological diagnoses were made, while 5 of the cases were misdiagnosed. Based on cytological examination, from 27 of the samples taken, $18(66,7 \%)$ were diagnosed as Suspect adenoma, $6(22,2 \%)$ as Suspect carcinoma and $3(11,1 \%)$ as Suspect epithelioma. Based on histopathological examination, of the total 32 cases, 22 (68,7\%) were diagnosed as Hepatoid gland adenoma (HGA), 7 (21,9\%) as Hepatoid gland carcinoma (HGC) and 3 (9,4\%) as Hepatoid gland epithelioma (HGE). These results suggest that the FNAC technique and cytological examination could be of use in the early diagnosis of canine hepatoid gland tumors.

Keywords: Dog, fine-needle aspiration cytology, hepatoid gland tumor, histopathology, malignancy.
\end{abstract}

\section{Köpek hepatoid bezi tümörlerinin tanısında ince iğne aspirasyon sitolojisi (İIAS): Histopatolojiyle karşılaştırmalı çalışma}

Özet: Bu çalışmada hepatoid bez tümörlerinin sitolojik ve histopatolojik bulguları karşılaştırılarak sitolojik tanının güvenirliği araştırıldı. Bu amaçla hepatoid bez tümörü şüphesi bulunan 32 farklı 1rk, yaş ve cins köpekten alınan örnekler kullanıldı. Sitolojik örnekler İnce İğne Aspirasyon Sitolojisi (İİAS) tekniğine göre alındı, havada kurutularak May-Grünwald Giemsa (MGG) ile boyandı. Histopatolojik inceleme amacıyla alınan dokular ise \%10'luk nötral formalin solüsyonunda tespit edilerek rutin doku takibine alınarak hematoksilen eozin (HE) ile boyandı. Çalışma sonucunda; 32 örneğin \%84.37'sinde sitolojik ve histopatolojik tanının örtüştüğü, buna karşılık 5 olguda hatalı tanıya gidildiği görüldü. Sitolojik olarak yapılan incelemelerde 27 örneğin 18 (\%66,7)' ine adenom, $6(\% 22,2)$ 'ine karsinom ve 3 (\%11,1)'üne benign-epitelyom tanısı konuldu. Histopatolojik olarak ise 32 olgunun 22 $(\% 68,7)$ 'ü hepatoid gland adenom (HGA), 7 (\%21,9)'i hepatoid gland karsinom (HGK) ve $3(\% 9,4)$ hepatoid gland epitelyom (HGE) olarak tespit edildi. Sonuç olarak köpeklerde hepatoid tümörlerde İİS tekniği ve sitolojik tanının erken tanıda yararlı olabileceği kanısina varıldi.

Anahtar sözcükler: hepatoid bez tümörü, histopatoloji, ince iğne aspirasyon sitolojisi, köpek, malignite.

\section{Introduction}

Hepatoid gland tumors generally originate from the sebaceous glands found around the anus of dogs. These tumors are located in the skin of the anus, the preputium and tail $(1,6,8,17)$. Due to the morphological appearance of tumor cells resembling that of hepatocytes, these tumors are referred to as "hepatoid gland tumors" $(8,15)$. Tumors are more frequently encountered in young and uncastrated male dogs. It is reported that the Husky, Cocker Spaniel and Terrier breeds are predisposed to hepatoid gland tumors $(1,8,16,23)$.

Histomorphologically, hepatoid gland tumors are classified under three groups, namely, hepatoid gland adenomas (HGA), hepatoid gland carcinomas (HGC) and hepatoid gland epitheliomas (HGE) $(8,15)$. While hepatoid gland carcinomas and epitheliomas are rare, adenomas occur more frequently. Although the metastasis tendency of hepatoid gland carcinomas is low, it has been reported that these tumors may invade the lymph nodes and liver $(1,8,18)$. The surface of this type of tumors is generally ulcerous and presents with haemorrhages $(3,6,20)$.

Cytological examination has gained popularity as it produces results within a shorter time period, is less costly and requires less equipment in comparison with the other diagnostic methods referred to above $(2,7,13$, 
22, 24). Although the number of cells derived with cytological sampling being low is perceived as a disadvantage, the possibility of repeating the procedure several times with minimal trauma to the patient is a major advantage compared to other diagnostic techniques $(2,10,13,14,22)$.

The present study aimed to investigate the usability of cytological examination, a method rarely consulted for the diagnosis of canine hepatoid gland tumors in Turkey, in veterinary medicine, and to make a comparative assessment of cytological and histopathological findings.

\section{Materials and Methods}

The study material comprised samples taken from 32 dogs of different breed, sex and age, which were admitted to the Surgery Clinics of Veterinary Faculties and private veterinary clinics province. Cytological samples were taken under mild sedation with diazepam (0.2 mg/kg, IV, Diazem, Deva) and ketamine $\mathrm{HCl}$ (5 $\mathrm{mg} / \mathrm{kg}$, IV, Ketamidor, Richter Pharma Ag) using a 20Gauge needle attached to a $10 \mathrm{ml}$ syringe and by the fine needle aspiration cytology (FNAC) technique by the pathologist. For aspiration; after the mass is stabilized between fingers needle is inserted periphery of the mass, negative pressures were applied with plunger of syringe at least 3-4 times at different angles of the tumors, syringe moved back and aspirate spouted onto the slides and smeared. Four smears were prepared for each tumor, after air-drying of smears they were stained with MayGrünwald Giemsa (MGG). All slides were examined under light microscope with 40x and 100x objectives. On the other hand, tissue samples taken under general anaesthesia by surgery were fixed in $10 \%$ neutral formalin solution. Following routine tissue processing, the tissue samples were embedded in paraffin. Fivemicron-thick sections cut from the paraffin blocks were stained with Haematoxylin-Eosin (H\&E). Based on the findings obtained and the comparison of the cytological and histopathological findings and in view of the skin tumor classification criteria laid down by the World Health Organisation (WHO) (21), the tumors detected in the dogs were classified as hepatoid gland adenoma, hepatoid gland carcinoma and hepatoid gland epithelioma.

\section{Results}

Of the 32 dogs included in the study, $13(40,6 \%)$ were Terriers, $6(18,8 \%)$ were mongrels, $4(12,5 \%)$ were Cocker Spaniels, 4 (12,5\%) were Rottweilers, 2 (6,3\%) were Golden Retrievers, 1 (3,1\%) was Labrador Retriever, $1(3,1 \%)$ was Pekingese and $1(3,1 \%)$ German Shepherd. Furthermore, $22(68,8 \%)$ of the animals were male and $10(31,2 \%)$ were female. Detailed data obtained in the study are shown in Table 1 . The mean age of the animals was $9 \pm 3$ years (range, 3-16 years). In 27 $(84,4 \%)$ of the 32 samples taken from the dogs included in the study, the cytological and histological diagnoses confirmed each other, whilst 5 of the cases (Case $\mathrm{n}^{\circ} 5$, $16,24,25,31)$ were misdiagnosed. Out of 27 of the cytological samples taken, $18(66,7 \%)$ were diagnosed with suspect hepatoid gland adenoma, $6(22,2 \%)$ with suspect hepatoid gland carcinoma and $3(11,1 \%)$ with suspect hepatoid gland epithelioma. The remaining 5 cytological samples were misdiagnosed due to the scarcity of the cellular material (Case $\left.n^{\circ} 5,16\right)$ and the presence of many inflammatory cells (Case $n^{\circ} 24,25$, 31). Based on histopathological examination, of the total 32 cases, $22(68,7 \%)$ were diagnosed with hepatoid gland adenoma, $7(21,9 \%)$ with hepatoid gland carcinoma and $3(9,4 \%)$ with hepatoid gland epithelioma. The relation between FNAC and final histopathologic diagnosis is shown in Table 1.

Clinical history: The dogs diagnosed with hepatoid gland tumor were in bad general health and presented with loss of appetite, polyuria, difficulty in defecating, lethargy and loss of body weight. Furthermore, hair loss, severe itching, haemorrhages and ulcers were observed in the hepatoid region.

Lesions description: The tumors, which were located around the anus and in the tail region, were observed to have invaded the skin and to be of soft or elastic consistency, a lobular structure and 1.0-8.0 cm diameter. Hair loss, ulcer and necrosis were observed on the surface of the tumors. Cross sections displayed the extension of the tumoral invasion into the muscle layer and a brown coloured multilobular structure associated with multiple haemorrhages and necrosis.

Cytologic findings: Prior to surgery, cytological samples were collected from 27 of the dogs by fine needle aspiration biopsy. The cytological characteristics of the perianal masses are summarized in Table 2 .

In the samples diagnosed with hepatoid gland adenoma, large cuboidal epithelial cells were observed either individually or in groups. The cytoplasm of these cells was dense, granular and of blue colour. In these cells very slight anisocytosis and anisokaryosis were observed (Figure 1A). Furthermore, the nucleus/ cytoplasm rate was low and the nucleus was round and rich in chromatin.

In the cytological samples diagnosed with hepatoid gland carcinoma, the cells and nuclei displayed evident pleomorphism and hyperchromasia (Figure 1B). The cytoplasm was of pale eosinophilic colour and generally contained vacuoles. The nuclei presented marked anisokaryosis and hyperchromasia. The cells containing giant nuclei were observed in association with multinucleated cells (Figure 1B, 1C). Mitotic figures were associated with abnormal chromatin structure (Figure 1D). 
Table 1. Signalment of dogs included in the present study and cytological and histopathological diagnoses.

Tablo 1. Çalışmada kullanılan köpeklere ait bulgular ile sitolojik ve histolojik tanılar.

\begin{tabular}{|c|c|c|c|c|c|}
\hline Case $\mathrm{n}^{\mathrm{o}}$ & Sex & Age & Breed & Cytological diagnosis & Histopathological diagnosis \\
\hline 1 & M & 6 & Mongrel & Suspect HGA & HGA \\
\hline 2 & M & 7 & Rottweiler & Suspect HGA & HGA \\
\hline 3 & M & 6 & Terrier & Suspect HGC & HGC \\
\hline 4 & $\mathrm{~F}$ & 9 & Rottweiler & Suspect HGC & HGC \\
\hline 5 & $\mathrm{~F}$ & 10 & Labrador Retriever & Suspect spindle cell neoplasm & HGA \\
\hline 6 & M & 3.5 & Terrier & Suspect HGA & HGA \\
\hline 7 & M & 13 & Terrier & Suspect HGC & HGC \\
\hline 8 & M & 8 & Golden Retriever & Suspect HGA & HGA \\
\hline 9 & M & 10 & Terrier & Suspect HGA & HGA \\
\hline 10 & M & 8 & Terrier & Suspect HGA & HGA \\
\hline 11 & $\mathrm{~F}$ & 7 & Mongrel & Suspect HGA & HGA \\
\hline 12 & M & 14 & Cocker Spaniels & Suspect HGE & HGE \\
\hline 13 & M & 5.5 & Terrier & Suspect HGA & HGA \\
\hline 14 & $\mathrm{~F}$ & 5 & Terrier & Suspect HGA & HGA \\
\hline 15 & M & 11 & Mongrel & Suspect HGE & HGE \\
\hline 16 & $\mathrm{~F}$ & 10 & Cocker Spaniels & Suspect spindle cell neoplasm & HGA \\
\hline 17 & $\mathrm{~F}$ & 9 & Cocker Spaniels & Suspect HGC & HGC \\
\hline 18 & M & 7 & Terrier & Suspect HGA & HGA \\
\hline 19 & M & 12 & Pekingese & Suspect HGC & HGC \\
\hline 20 & $\mathrm{~F}$ & 13 & Golden Retriever & Suspect HGA & HGA \\
\hline 21 & M & 7.5 & Rottweiler & Suspect HGA & HGA \\
\hline 22 & M & 9.5 & Terrier & Suspect HGA & HGA \\
\hline 23 & M & 16 & Terrier & Suspect HGC & HGC \\
\hline 24 & $\mathrm{~F}$ & 16 & Terrier & Atypical lymphoid population & HGC \\
\hline 25 & M & 14 & Mongrel & Atypical lymphoid population & HGA \\
\hline 26 & M & 10 & Rottweiler & Suspect HGA & $\mathrm{HGA}$ \\
\hline 27 & M & 8 & Terrier & Suspect HGE & HGE \\
\hline 28 & M & 15 & Cocker Spaniels & Suspect HGA & HGA \\
\hline 29 & M & 10 & German Shepherd & Suspect HGA & HGA \\
\hline 30 & $\mathrm{~F}$ & 12 & Terrier & Suspect HGA & HGA \\
\hline 31 & M & 8 & Mongrel & Atypical lymphoid population & HGA \\
\hline 32 & $\mathrm{~F}$ & 9 & Mongrel & Suspect HGA & HGA \\
\hline
\end{tabular}

HGA: Hepatoid gland adenoma, HGC: Hepatoid gland carcinoma, HGE: Hepatoid gland epithelioma, n: Number, M: Male, F: Female.

Table 2. Malignant cytological criteria of hepatoid glad tumors.

Tablo 2. Hepatoid bez tümörlerinde görülen malign sitolojik kriterler.

\begin{tabular}{lccc}
\hline Cytological criteria & HGA & HGC & HGE \\
\hline Pleomorphism & $0 / 19$ & $5 / 5$ & $1 / 3$ \\
Macronuclei & $1 / 19$ & $5 / 5$ & $1 / 3$ \\
Abnormal nuclei & $1 / 19$ & $5 / 5$ & $0 / 3$ \\
Coarse chromatin pattern & $0 / 19$ & $5 / 5$ & $0 / 3$ \\
Double nucleus & $0 / 19$ & $3 / 5$ & $0 / 3$ \\
Uniform cells & $19 / 19$ & $0 / 5$ & $2 / 3$ \\
Spindle shaped cells & $0 / 19$ & $1 / 5$ & $0 / 3$ \\
Hypercellularity & $5 / 19$ & $2 / 5$ & $3 / 3$ \\
Debris & $0 / 19$ & $4 / 5$ & $1 / 3$ \\
Mitotic index & $0 / 19$ & $3 / 5$ & $0 / 3$ \\
Inflammatory cells & $1 / 19$ & $4 / 5$ & $3 / 3$ \\
\hline
\end{tabular}

HGA: Hepatoid gland adenoma, HGC: Hepatoid gland carcinoma, HGE: Hepatoid gland epithelioma. 

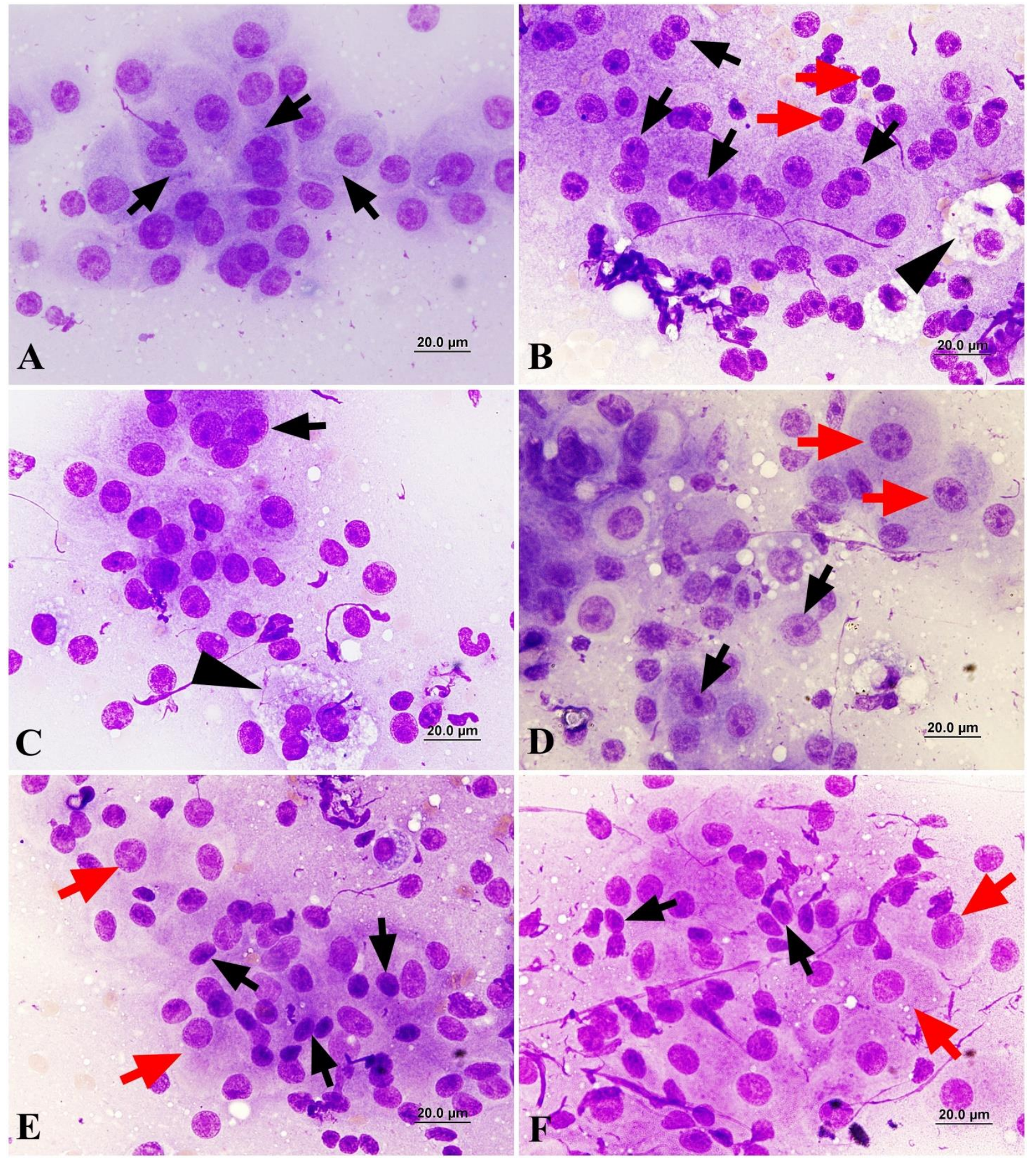

Figure 1. A. Aspirate from perianal gland adenoma (case $\left.n^{0} 11\right)$ : Large hepatoid cells showing a mild pleomorphism, granular cytoplasm (arrows), MGG. B. Perianal gland carcinoma (case $\mathrm{n}^{\circ}$ 4): Cells showing prominent criteria for malignancy, micronucleoli (red arrows), cell with vacuolated cytoplasm (arrowhead) and big multinucleate cells (arrows), MGG. C. Perianal gland carcinoma (case $\mathrm{n}^{\circ}$ 19): Big multinucleate cells (arrow) and with vacuolated cytoplasm (arrowhead), MGG. D. Perianal gland carcinoma (case $\mathrm{n}^{\circ}$ 17): Nuclei presented with hyperchromasia (arrows) and abnormal chromatin structure (red arrows), MGG. E. Perianal gland epithelioma (case $\mathrm{n}^{\circ}$ 27): Small basaloid epithelial cells (arrows) in a between of hepatoid like cells (red arrows), MGG. F. Perianal gland epithelioma (case $\mathrm{n}^{\circ}$ 15): Basaloid cells (arrows) in between mild pleomorphism hepatoid tumor cells (red arrows), MGG.

Şekil 1. A. Perianal bez adenomundan alınan aspirat (olgu $\left.n^{\circ} 11\right)$ : Hafif pleomorfizim gösteren büyük hepatosit benzeri hücreler, granüler sitoplazma (oklar), MGG. B. Perianal bez karsinomu (olgu n ${ }^{\circ}$ 4): Belirgin atipik özellikler gösteren hücreler, mikronükleus (kırmızı oklar), vakuoler sitoplazma (ok başı) ve büyük çok çekirdekli hücreler (oklar), MGG. C. Perianal bez karsinomu (olgu ${ }^{\circ}$ 19): Belirgin malignite gösteren hücreler, büyük çok çekirdekli hücre (ok) ve vakuoler sitoplazmalı çok çekirdekli hücre (ok baş1), MGG. D. Perianal bez karsinomu (olgu n $\left.{ }^{\circ} 17\right)$ : Hiperkromatik çekirdekcik (oklar) ve anormal kromatin yapısı (kırmızı oklar), MGG. E. Perianal bez epitelyom (olgu ${ }^{\circ}$ 27): Hepatosit benzeri hücreleri (kırmızı oklar) arasında küçük basaloid epitel hücreleri (oklar), MGG. F. Perianal bez epitelyom (olgu n ${ }^{\circ} 15$ ): Hafif pleomorfik hepatosit benzeri hücreler (kırmızı oklar) arasındaki basaloid hücreler (oklar), MGG. 

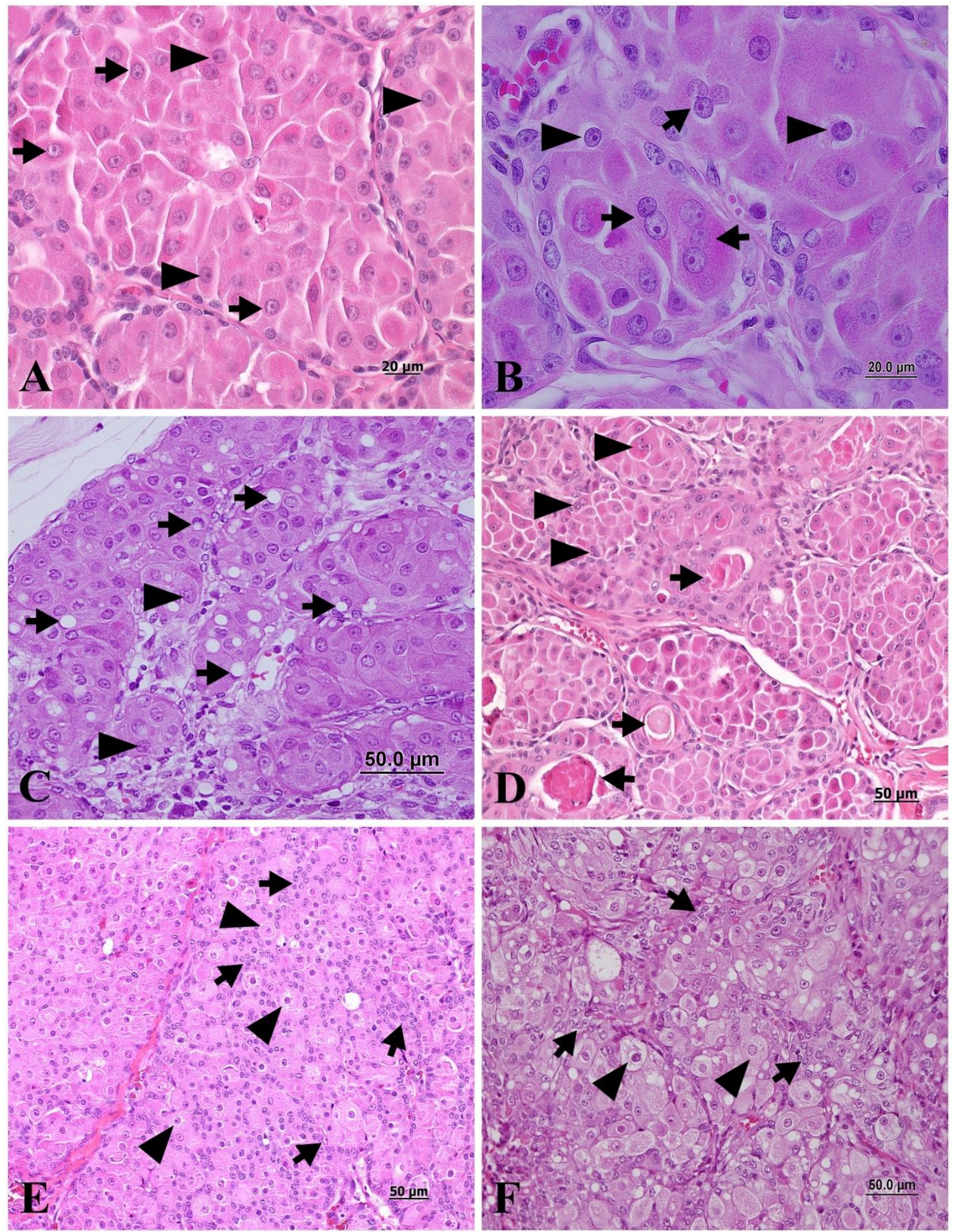

Figure 2. A. Perianal gland adenoma (case $\left.n^{\circ} 11\right)$ : Hepatoid cells with vesicular nucleus (arrows) and hyperchromatic nucleolus (arrowheads), H\&E. B. Perianal gland carcinoma (case $\mathrm{n}^{\circ} 4$ ): Big multinucleate cells (arrows) and micronucleoli (arrowheads), H\&E. C. Perianal gland carcinoma (case $\mathrm{n}^{\mathrm{o}} 19$ ): The cells with numerous vacuolated cytoplasm (arrows) and macronucleoli (arrowheads), H\&E. D. Perianal gland carcinoma (case $\mathrm{n}^{\mathrm{o}} 17$ ): Squamous metaplasia (arrows) and big multinucleate cells (arrowheads), H\&E. E. Perianal gland epithelioma (case $\mathrm{n}^{\circ} 27$ ): Hepatoid cells (arrowheads) organized in nests with a thick basaloid cells layer (arrows), H\&E. F. Perianal gland epithelioma (case $n^{\circ} 15$ ): Hepatoid cells with vacuolated cytoplasm (arrowheads) organized in nests with a thick basaloid cells layer (arrows), H\&E.

Şekil 2. A. Perianal bez adenom (olgu $\mathrm{n}^{\circ} 11$ ): hepatosit benzeri veziküler çekirdekli (oklar) ve hiperkromatik çekirdekcikli (ok başları) hücreler, HE. B. Perianal bez karsinomu (olgu ${ }^{\circ}$ 4): Çok çekirdekli hücreler (oklar) ve mikronükleus yapısı (ok baș1), HE. C. Perianal bez karsinomu (olgu $\mathrm{n}^{\circ}$ 19): Çok sayıda sitoplazmik vakuol içeren hücre (oklar) ve makronükleus (ok başları), HE. D. Perianal bez karsinomu (olgu $\left.n^{\circ} 17\right)$ : Skuamöz metaplazi (oklar) ve büyük çok çekirdekli hücreler (oklar), HE. E. Perianal bez epitelyoma (olgu n ${ }^{\circ}$ 27): Küçük bazaloid epitel hücreleri (oklar) arasında hepatosit benzeri hücreler (ok başları), HE. F. Perianal bez epitelyoma (olgu ${ }^{\circ}$ 15): Küçük bazaloid epitel hücreleri (oklar) arasında vakuoler sitoplazmalı hepatosit benzeri hücreler (ok başları), HE. 
In the samples diagnosed with epithelioma, large cuboidal epithelial cells with a broad basophilic cytoplasm were presented with very slight anisocytosis and anisokaryosis. The nucleus/cytoplasm rate was low and pleomorphism was of light intensity (Figure 1E, 1F). These cells were associated with a high number of small round basaloid cells containing a narrow cytoplasm. Pleomorphism was of light intensity and mitotic figures were observed in very low numbers.

Histopathological findings: Of the 32 cases examined histologically, $22(68,7 \%)$ were diagnosed with hepatoid gland adenoma, $7(21,9 \%)$ with hepatoid gland carcinoma and $3(9,4 \%)$ with hepatoid gland epithelioma.

In the hepatoid gland adenomas, hepatocyte-like hepatoid gland epithelial cells with a polyhedral shape, markedly eosinophilic cytoplasm, large, ovoid and vesicular nucleus and hyperchromatic nucleolus (Figure 2A), were found to occupy large areas within a thin stroma rich in blood vessels, either in the form of islets or trabeculae. These islets were surrounded by a single layer of basaloid tumor cells, which were characterized by a narrow cytoplasm and a small, hyperchromatic nucleus. All these structures were surrounded by a capsule composed of a broad layer of connective tissue.

In the cases of hepatoid gland carcinoma, the cells were presented with marked pleomorphism and distributed irregularly in the stroma. The cytoplasm of the cells was pale and eosionophilic, and generally vacuolated. Giant cells with multinucleated were observed (Figure 2B, 2C). It was observed that some of the cells had undergone squamous metaplasia (Figure 2D). Pleomorphism was evident in the nuclei and mitotic figures were common. In the tumors that presented with ulcer, inflammatory cell infiltrations containing many neutrophil leukocytes were observed beneath the epidermis in association with haemorrhagic areas.

In the hepatoid gland epitheliomas, hepatoid cells that were surrounded by a thin capsule and displayed slight atypical features were observed to be arranged in the form of islets. In-between these islets, basaloid epithelial cells with a narrow cytoplasm and a small and hyperchromatic nucleus, were found in high numbers (Figure 2E, 2F). While these cells presented with mitotic figures, their nucleus displayed slight pleomorphism.

\section{Discussion and Conclusion}

The main target of all diagnostic methods is to enable a rapid, reliable and economic diagnosis to be made within the shortest time possible with minimum damage to the patient $(5,9,14,22)$. The use of cytological examination, which enables rapid diagnosis with the use of minimal laboratory equipment and is a practical method, has started to increase in veterinary medicine. The fine needle aspiration cytology (FNAC) technique has been used in the diagnosis of human breast, thyroid and skin cancer for many years and has provided the opportunity of early treatment owing to the early diagnosis of malignant cases $(14,19,22,24)$. The increased use of the FNAC technique in veterinary medicine has brought about similar results. In agreement with literature reports, in the present study, the use of the FNAC technique was not associated with any adverse effect and its application was found to be quite successful in dogs under light sedation.

Despite the above-mentioned advantages, cytological examination may result in misdiagnosis in the event of the examination being made by inexperienced persons, as well as due to the sample lacking a tissue structure, blood cells dominating tumor cells in samples taken from bloody tissues, or a sufficient amount of cells not being able to be sampled $(2,7,12,22,24)$. In the present study, possible application errors were avoided by the cytological examination being performed by experienced pathologists. In case a definitive diagnosis cannot be made by cytological examination, it would be of use to consult histopathological examination for confirmation $(2,12,14,19)$. In a research on skin tumors, based on confirmation with histological examination, Ghisleni et al. (7) reported the accuracy of cytopathological examination as $83.2 \%$. Again, based on confirmation with histopathological examination, the accuracy rate of cytological examination was reported as $90,9 \%$ by Macneill (13) and as $88,5 \%$ by Haziroglu et al. (12) in canine mammary tumors. Furthermore, the accuracy rate of cytological diagnosis in canine mammary tumors was reported as $92,9 \%$ by Casalli et al. (4) and as $81,4 \%$ by Simeonov and Stoikov (19) In the present study, it was determined that in 5 cases the cytological diagnosis differed from the histological diagnosis, whilst in $84,37 \%$ of the cases the cytological and histopathological findings confirmed each other.

In dogs, perianal glands are sebaceous structures located around the anus. The odour of perianal gland secretion aids dogs in recognizing each other, and thus, in their communication $(1,6,8)$. Tumors of the hepatoid glands are encountered more frequently in senile and uncastrated $\operatorname{dogs}(3,11,20,23)$. Having investigated androgen receptors in normal and neoplastic hepatoid glands, Pisani et al. (16) reported that these receptors were found in higher numbers in neoplastic glands compared to normal glands. In the present study, in agreement with literature reports, all of the sampled male dogs, which were diagnosed with hepatoid gland tumors, were uncastrated. Previous research on hepatoid gland tumors has shown that these tumors occur more frequently in the Siberian Husky, Samoyed and Pekingese dog breeds $(1,3,8,17,23)$. In the present study, Terriers ranked first $(40,6 \%)$ for the occurrence of hepatoid gland tumors and were followed by mongrels 
$(18,8 \%)$. The fact that the findings obtained for the dog breeds diagnosed with hepatoid gland tumors in the present study differing from that indicated in literature reports is attributed to the Siberian Husky and Samoyed not being commonly bred in Turkey.

In general, metastases are not observed in hepatoid gland tumors, and their surgical extirpation produces good results, yet malignant tumors have been reported to invade the lungs, liver, spleen and regional lymph nodes $(15,20,23)$. After the end of the study and during the period in which the dogs were monitored, no metastases or postoperative complications were observed in any of the dogs. Clinically, hepatoid gland tumors are associated with polyuria and difficulty in defecating $(1,8,16,20$, 23). In this study and in particular in the dogs with tumors of a diameter larger than $2 \mathrm{~cm}$, similar clinical symptoms were observed. Following the extirpation of the tumors, these symptoms disappeared.

The cytological criteria used for determining the malignancy of tumors include the number of nucleoli, nuclear anomalies, the presence of giant nucleoli, the nucleus/cytoplasm rate, chromatin structure, and the presence of giant cells with multiple nuclei $(12,14,19$, $22,24)$. In the present study, the malignant hepatoid gland tumors were differentiated based on these criteria.

In the histological examination of malignant hepatoid gland tumors, squamous metaplasia and alterations in ductal structure are frequently observed $(8$, 17, 21, 23). In the present study, of the 5 (Case $n^{0} 3,4,7$, 17, 19) malignant tumors diagnosed, 3 (Case $n^{0} 3,4,7$ ) were presented with squamous metaplasia and 4 (Case $n^{\circ}$ 3, 7, 17, 19 ) exhibited ductal alterations. On the other hand, in benign tumors, the tumor islets are surrounded by basaloid cells. Basaloid cells were also detected in the benign tumors diagnosed in the present study.

It was concluded that the fine needle aspiration biopsy technique served as a rapid, low-cost and readily applicable method with minimal damage to the patient in the diagnosis of canine hepatoid gland tumors. Furthermore, in view of the fact that in most cases the lesions were accessible and the cytological material was of an adequate amount, the FNAC technique was considered to provide significant advantages in the diagnosis of hepatoid gland tumors.

\section{References}

1. Berrocal A, Vos JH, Van Den Ingh T, et al. (1989): Canine perianal tumors. Zentralbl Veterinarmed A, 36, 739-749.

2. Berzina I, Sharkey LC, Matise I, et al. (2008): Correlation between cytologic and histopathologic diagnoses of bone lesions in dogs: a study of the diagnostic accuracy of bone cytology. Vet Clin Pathol, 37, 332-338.

3. Betini G, Morini M, Campagna F, et al. (2005): True grit: the tale of a subcutaneous mass in a dog. Vet Clin Pathol, 34, 73-75.
4. Casalli GD, Gobbi H, Malm C, et al. (2007): Evaluation of accuracy of fine needle aspiration cytology for diagnosis of canine mammary tumors: comparative features with human tumors. Cytopathology, 18, 191-196.

5. Daskalopoulou D, Maounis N, Kokalis G, et al. (1993): The role of fine needle aspiration cytology in the diagnosis of primary skin tumors. Arch Anal Cytol Path, 41, 75-81.

6. Genevois JP (1980): Pathologie ano-rectale et perineale, $i$ circumanalomes. Revue Méd Vét, 131, 697-705.

7. Ghisleni G, Roccabianca P, Ceruti R, et al. (2006): Correlation between fine-needle aspiration cytology and histopathology in the evaluation of cutaneous and subcutaneous masses from dogs and cats. Vet Clin Pathol, 35, 24-30.

8. Goldschmidt MH, Hendrick MJ (2002): Tumors of the skin and soft tissues. In: Meuten DJ, ed. Tumors in domestic animals. 4th ed. Iowa State Press, Iowa, 45-117.

9. Griffiths GL, Lumsden JH, Vali V (1984): Fine-needle aspiration cytology and histologic correlation in canine tumors. Vet Clin Pathol, 13, 13-17.

10. Hall RL, Macwilliams PS (1988): The cytologic examination of cutaneous and subcutaneous masses. Semin Vet Med Surg, 3, 94.

11. Hayes HM, Wilson G (1977): Hormone-dependent neoplasms of the canine perianal gland. Cancer Res, 37, 2068-2071.

12. Haziroglu R, Yardimci B, Aslan S, et al. (2010): Cytological evaluation of canine mammary tumors with fine needle aspiration biopsy technique. Revue Méd Vét, 161, 212-218.

13. Macneill AL (2011): Cytology of canine and feline cutaneous and subcutaneous lesions and lymph nodes. Top Companion Anim Med, 26, 62-76.

14. Morrison WB, Denicola DB (1993): Advantages and disadvantages of cytology and histopathology for the diagnosis of cancer. Semin Vet Med Surg, 8, 222-227.

15. Nielsen SW, Aftosmis J (1964): Canine perianal gland tumors. J Am Vet Med Assoc, 144, 127.

16. Pisani G, Millanta F, Lorenzi D, et al. (2006): Androgen receptor expression in normal, hyperplastic and neoplastic perianal glands in the dog. Res Vet Sci, 81, 231-236.

17. Sharif MAM (2006): Epidemiology of skin tumors entities according to the new WHO classification in dogs and cats. VVB, Laufersweiler Verlag, Giessen, Germany, 1-190.

18. Simeonov R, Simeonova G (2008): Computer-Assisted nuclear morphometry in the cytological evaluation of canine perianal adenocarcinomas. J Comp Path, 139, 226230.

19. Simeonov R, Stoikov D (2006): Study on the correlation between the cytological and histological tests in the diagnostics of canine spontaneous mammary neoplasms. BJVM, 9, 211-219.

20. Vail DM, Withrow SJ, Schwarz PD, et al. (1990): Perianal adenocarcinomas in the canine male: a retrospective study of 41 cases. J Am Anim Hosp Assoc, 26, 329-334.

21. Weiss E, Frese F (1974): Tumors of the skin. Bull Wld Hlth Org, 50, 79-100.

22. Wellman ML (1990): The cytologic diagnosis of neoplasia. Vet Clin North Am Small Anim Prac, 20, 919937. 
23. Wilson GP, Hayes HM (1979): Castration for treatment of perianal gland neoplasms in the dog. $\mathrm{J}$ Am Vet Med Assoc, 174, 1301-1303.

24. Yildirim F, Gurel A (2012): Comparison between cytological and histopathological evaluations of canine mammary tumors. Revue Méd Vét, 163, 116-122.
Geliş tarihi: 01.07.2015 / Kabul tarihi: 13.10.2015

Address for correspondence:

Dr. Nihat Yumuşak

University of Harran,

Faculty of Veterinary Medicine

Department of Pathology,

Eyyubiye-Şanliurfa/Turkey

e-mail:nihatyumusak@harran.edu.tr 